\title{
Pre-treatment of eucalypts biomass towards enzymatic saccharification
}

\author{
Washington Luiz Magalhães ${ }^{1 *}$, Cristiane Helm¹, Patricia Silva', Edson Lima', Kleber Hoffman², Amanda Higa², \\ Tielidy Lima² \\ From IUFRO Tree Biotechnology Conference 2011: From Genomes to Integration and Delivery \\ Arraial d Ajuda, Bahia, Brazil. 26 June - 2 July 2011
}

\section{Background}

There are a few possible ways to produce ethanol from lignocellulosic biomass, for instance, thermochemical and acid hydrolysis. However, enzymatic hydrolysis of carbohydrates is considered the greenest process for saccharification, followed by sugar fermentation into ethanol.

The main challenge of the enzymatic saccharification process is that cellulose is not exposed to the enzyme action in the lignin matrix. The cellulose molecules are arranged in semi-crystalline nanofibrils immersed in lignin matrix with hemicelluloses (polyoses) and extractives between them acting as coupling agents. These nanofibrils are placed together to form helical microfibrils inside the cell wall. Thus, a pre-treatment is necessary to make room for the enzymes to reach the cellulose fibril surfaces in order for the whole process to become economically feasible.

There are many pre-treatments proposed in specialized literature, but their efficiencies are dependent on the biomass composition [1-4]. Moreover, these treatments have to address some constraints such as the recyclability of the chemicals used, low consumption of energy, and sustainability concerns.

We devised a future possibility of a cellulose pulp mill to be transformed into a biorefinary, where besides cellulose pulp, ethanol could also be produced. In the Brazilian pulp mill industry, the process most commonly used is the Kraft process, so the digestion with green and white liquors can be adapted for pre-treatment towards enzymatic saccharification. Also, the industry had already tackled recycling of the black liquor obtained after wood chips digestion -, recuperating

* Correspondence: wmagalha@cnpf.embrapa.br

${ }^{1}$ Embrapa Forestry, Brazil

Full list of author information is available at the end of the article thermal energy by burning lignin and recovering the green liquor.

This work is part of our research to evaluate some modifications on the green liquor digestion towards enzymatic saccharification. We evaluated efficiencies of some pre-treatments with green liquor through enzymatic hydrolysis for holocellulose saccharification.

\section{Methods}

A wood $\log$ from a 7-year old tree of Eucalyptus benthamii was cut into discs. They were cut into $30^{\circ}$ wedges and were then grounded using a Willey mill and sifted to be between 20 and 40 Tyler mesh.

Composition of the E. benthamii wood obtained by NBR standards was: $3 \%$ of total extractives; $28.4 \%$ of Klason lignin; $0.03 \%$ of ash and 3.5 of syringyl:guaiacyl molar ratio.

Table 1 shows the characterization of the green liquor acquired from Iguaçu Celulose Papel S.A.

The pre-treatment conditions used in this study were two levels of temperature -120 and $180{ }^{\circ} \mathrm{C}-$ and three levels of reaction time $-1,2$, and 3 hours. Cylindrical stainless steel reactors (Parr, USA) with volume capacity of $50 \mathrm{~mL}$ were used. The reactors were heated in an aluminum dry block furnace (Marconi, Brazil) with a temperature and time controller. The ratio of solid wood and green liquor was 1:4 (g.mL $\left.{ }^{-1}\right)$. Typical values were $4 \mathrm{~g}$ of dry biomass in $16 \mathrm{~mL}$ of green liquor per reactor.

The pre-treated biomass was digested using Falcon tubes with enzymes in a buffer solution of sodium citrate ( $\mathrm{pH}$ of 5.0) in an incubator (Tecnal TE-420, Brazil) at $50{ }^{\circ} \mathrm{C}$ and $250 \mathrm{rpm}$ during 24 hours. The enzymes used were cellobiase from Aspergillus niger (Novozyme 188) and cellulase from Trichoderma reesi (ATCC 26921), acquired from Sigma Aldrich, USA. Typically, 
Table 1 Characterization of the industrial green liquor used in this work.

\begin{tabular}{|c|c|}
\hline Analysis of green liquor & $\begin{array}{c}\text { Content }\left(g \cdot \mathbf{L}^{-}\right. \\
\left.{ }^{\prime}\right)\end{array}$ \\
\hline Content of sodium sulfide $(X)$ in $\mathrm{Na}_{2} \mathrm{~S}$ & 14.59 \\
\hline Content of sodium sulfite $(\mathrm{Y})$ in $\mathrm{Na}_{2} \mathrm{SO}_{3}$ & 13.9 \\
\hline Content of sodium thiosulfate $(Z)$ in $\mathrm{Na}_{2} \mathrm{~S}_{2} \mathrm{O}_{3}$ & 3.16 \\
\hline Total alkali (concentration of alkaline constituents: $\mathrm{OH}^{-}+\mathrm{HS}^{-}+\mathrm{HCO}_{3}{ }^{-}$) expressed in $\mathrm{NaOH}$ & 114.1 \\
\hline $\begin{array}{l}\text { Active alkali (sum of concentrations of hydroxyl and hydro-sulfite ions including ions formed by hydrolysis of sulfides: } \mathrm{OH}^{-}+\mathrm{HS}^{-} \text {) } \\
\text { expressed in } \mathrm{NaOH}\end{array}$ & 43.3 \\
\hline Effective alkali (concentration of hydroxyl ions including those formed from sulfides by hydrolysis: $\mathrm{OH}-$ ) expressed in $\mathrm{NaOH}$ & 32.5 \\
\hline Sulfidity & $33.7 \%$ \\
\hline
\end{tabular}

the proportion was $0.2 \mathrm{~g}$ of dry biomass, $40 \mathrm{ml}$ of buffer solution, $46 \mathrm{~mL}$ of cellobiase and $90 \mathrm{~mL}$ of cellulase (both used as received). After saccharification, the hydrolyzate was filtered and the reducing sugars were quantified through the dinitrosalicylic acid (DNS) method.

\section{Results}

Table 2 shows the solid mass loss after treatment, the total reducing sugar after enzymatic hydrolysis, and the global yield of saccharification.

As can readily be seen on Table 2, temperature plays a crucial role in exposing cellulose for enzymatic hydrolysis, as does the length of cooking. For lowest temperatures, $\left(120{ }^{\circ} \mathrm{C}\right)$ increasing time causes increased sugar release and conversion yield. On the other hand, for the highest temperature level $\left(180{ }^{\circ} \mathrm{C}\right)$, the time of cooking plays a more complex role. The treatment at $180{ }^{\circ} \mathrm{C}$ after 1 hour reaches the highest sugar conversion based on holocellulose content of untreated biomass.

The above results can be explained by the following suppositions. Increasing treatment time to 2 and 3 hours results in hemicellulose and amorphous cellulose losses, which decreased conversions yield. However, when the treatment time was increased to 3 hours, besides amorphous holocellulose loss, there was also the

Table 2 Mass loss after pre-treatment, total reducing sugar released after enzymatic digestion, and the yield of conversion based on holocellulose content in the untreated biomass.

\begin{tabular}{lccc}
\hline Treatment & $\begin{array}{c}\text { Mass } \\
\text { loss } \\
(\%)\end{array}$ & $\begin{array}{c}\text { Total reducing } \\
\text { sugar (kg.kg } \mathbf{- 1}^{-1} \text { of } \\
\text { treated biomass) }\end{array}$ & $\begin{array}{c}\text { Yield of sugar conversion } \\
\text { based on holocellulose of } \\
\text { untreated biomass (\%) }\end{array}$ \\
\hline untreated & 0.0 & 0.04 & 5.6 \\
$120^{\circ} \mathrm{C}, 1 \mathrm{~h}$ & 26.5 & 0.10 & 10.6 \\
$120^{\circ} \mathrm{C}, 2 \mathrm{~h}$ & 26.4 & 0.13 & 14.1 \\
$120^{\circ} \mathrm{C}, 3 \mathrm{~h}$ & 34.3 & 0.16 & 15.6 \\
$180^{\circ} \mathrm{C}, 1 \mathrm{~h}$ & 47,3 & 0.92 & 70.7 \\
$180^{\circ} \mathrm{C}, 2 \mathrm{~h}$ & 52.5 & 0.78 & 53.9 \\
$180^{\circ} \mathrm{C}, 3 \mathrm{~h}$ & 50.8 & 0.91 & 65.7 \\
\hline
\end{tabular}

occurrence of crystalline modification of part of the crystalline cellulose type I into amorphous and cellulose type II. Both amorphous and crystalline type II cellulose are enzymatic digested easier than crystalline type I cellulose. This could explain why sugar conversion yield after 2 hours of treatment at $180{ }^{\circ} \mathrm{C}$ are smaller than after 3 hours. XRD and chemical characterizations of the pre-treated biomass have to be done in order to corroborate with the above suppositions.

\section{Conclusion}

Simple modifications of the Kraft process can be considered as an alternative route for pre-treatment of woody biomass towards enzymatic saccharification.

\section{Acknowledgements}

We would like to gratefully acknowledge the Brazilian agency CNPq for the generous provision of a research fellowship to WLEM and also the English language revision by Miss Bia Carneiro.

\section{Author details}

${ }^{1}$ Embrapa Forestry, Brazil. ${ }^{2}$ UFPR, Brazil.

Published: 13 September 2011

\section{References}

1. Wyman CE, Dale BE, Elander RT, Holtzapple M, Ladisch MR, Lee YY: Coordinated development of leading biomass pretreatment technologies. Bioresour Technol 2005, 96:1959-1966.

2. Perez JA, Ballesteros I, Ballesteros M, Saez F, Negro M, Manzanares P: Optimizing liquid hot water pretreatment conditions to enhance sugar recovery from wheat straw or fuel-ethanol production. Fuel 2008, 87:3640-3647.

3. Monavari S, Galbe M, Zacchi G: Impact of impregnation time and chip size on sugar yield in pretreatment of softwood for ethanol production. Bioresour Technol 2009, 100:6312-6316.

4. Virkajärvi I, Niemelä MV, Hasanen A, Teir A: Cellulosic ethanol via biochemical processing poses a challenge for developers and implementors. BioResources 2009, 4:1718-1735.

doi:10.1186/1753-6561-5-S7-P116

Cite this article as: Magalhães et al:: Pre-treatment of eucalypts biomass towards enzymatic saccharification. BMC Proceedings 2011 5(Suppl 7): P116. 